\title{
Analysis of spatial-temporal clusters of childhood cancer incidence in the province of Córdoba, Argentina (2004-2013)
}

\author{
Lisandro Agost, B.S. ${ }^{a}$
}

\begin{abstract}
Introduction. In spite of its low incidence, childhood cancer is becoming increasingly more relevant in Argentina. More advances have been made in cancer treatment than in the study of its etiology or determining factors. There are no investigations that analyze its spatial and temporal distribution or potential clustering.

Objective. To perform exploratory spatial and temporal analyses based on the database of the Registry of Tumors of the Province of Córdoba (2004-2013) to determine the clustering of childhood cancer incidence in Córdoba (Argentina).

Populations and methods. Epidemiological, retrospective, ecological study. Data from 1098 patients with malignancies aged 0-14 years old from the Registry of Tumors of the Province of Córdoba (2004-2013) were used. A geographic information system model was developed. The presence of spatial, temporal, and spatialtemporal clusters was analyzed in the districts of Córdoba using the SaTScan software.

Results. Spatial clusters were detected, with a high number of cases, for total tumors $(p=0.01)$, leukemias $(p=0.02)$, malignant neoplasms of lymphoid, hematopoietic and related tissue $(p=0.03)$, central nervous system tumors $(p=0.03)$, and a high level of indicators of risk for renal tumors $(p=0.01)$. In addition, a temporal cluster $(p=0.01)$ and a spatial-temporal cluster ( $p=0.02)$ for neuroblastoma and other peripheral nervous cell tumors were also observed.

Conclusions. Significant clusters were determined, with importantassociated indicators observed in several districts of Córdoba. This is the first methodological step towards the development of new investigations on the risk factors for childhood cancer and its etiology.
\end{abstract}

a. Chair of Anthropology, School of Exact,

Physical and Natural

Sciences, Universidad

Nacional de Córdoba.

Córdoba, Argentina.

E-mail address:

Lisandro Agost, B.S.:

lisandroagost@gmail.com

Funding:

None.

Conflict of interest:

None.

Received: 4-08-2016 Accepted: 6-22-2016

\section{INTRODUCTION}

Advances made in pediatric health care have led to an epidemiological transition in the 0-14 year old group in Argentina. Thus, in the face of a reduction in the relative burden of infectious diseases and malnutrition, the importance of childhood cancer is becoming increasingly more evident, in spite of its low incidence. ${ }^{1,2}$ Childhood cancer refers to a group of diseases of multifactorial origin, for which more advances have been made in terms of treatment than in the study of their etiology or determining factors. ${ }^{3-7}$ Although the origin or influence factors of these diseases consider both genetic and environmental factors (and their interaction), many investigations suggest that the environment carries far more weight. ${ }^{4,5,8-10}$ Environmental factors refer to anything in interaction with the child, that is not related to a hereditary trait, and that may influence the development of cancer in the pediatric or adult stage..$^{4,5}$ Given such complex scenario, i.e. the multifactorial origin of cancer and the lack of knowledge on its etiology or associated factors in children, it is critical to have information provided by official registries based on analytical tools that enable the overlapping and interaction of various data in a cohesive and objective manner in the search for new forms of data stratification and visualization. ${ }^{11}$ Geographic information systems (GIS), together with cluster analysis tools, establish the first approach to delimiting research on specific population groups and/ or areas and make it effective, helping to the future knowledge of childhood cancer etiology. ${ }^{7,11}$

The objective of this research project is to perform exploratory spatial-temporal analyses based on the database of the Registry of Tumors of the Province of Córdoba (20042013) to determine the clustering of childhood cancer incidence in Córdoba (Argentina). 


\section{POPULATION AND METHODS}

This was an epidemiological, retrospective, ecological study. The study region is made up of the 26 districts of the province of Córdoba (spatial analysis units). As per the National Census of 2010, the province has 3304825 inhabitants, and 805512 of them are younger than 15 years of age. ${ }^{12}$

Data were provided by the Registry of Tumors of the Province of Córdoba, which depends on the Provincial Ministry of Health. It is a hospital-based registry arranged as a network of reporting sites. ${ }^{13}$

For the proposed study, data from 1098 patients with tumors aged 0-14 years old, corresponding to the 2004-2013 period, were used; these patients had a registered address in the province of Córdoba. The database was classified as per the International Classification of Diseases, $10^{\text {th }}$ revision (ICD-10), and the International Classification of Childhood Cancer, $3^{\text {rd }}$ edition (ICCC-3), thus allowing data grouping. In order to compare these data with those of other registries, frequency indexes, crude rates, and standardized rates were estimated for the overall group and for childhood cancer subgroups (standardized rates were estimated using the direct method of the "old standard world population" defined by Doll and Waterhouse and recommended by the World Health Organization).$^{14}$

Once data were classified, a geo-referenced database was developed using GIS for the representation of data and the development of new data for the subsequent cluster analyses. Polygonal layer files were used to represent the province and the different districts, provided by the Geoportal of the government of the province of Córdoba. ${ }^{15}$

Spatial, temporal, and spatial-temporal analyses of childhood cancer were done using the SaTScan software, which determines the presence of spatial and temporal clusters. ${ }^{16}$

SaTScan is a three-dimensional analytical tool based on the geographic and temporal location of cases. This is an exploratory methodology, and its purpose is to detect and locate clusters with a higher frequency of cancer occurrence than that expected for the studied region. The software analyzes "spaces" or "windows" shaped like a cylinder, with a centroid and definite radius. The general software procedure consists in analyzing the risk for the occurrence of an event of interest within each "window" and comparing it to the rest of the studied territory. This methodology is based on the assumption that cases have a
Poisson-like distribution, which is the probability distribution used to analyze discrete outcome measures that represent rare events. ${ }^{16}$ The tested null hypothesis is that the risk for the epidemiological event of interest remains constant over space and time, i.e., there is no clustering. The alternative hypothesis proposes that, for at least one of the cylinders, the risk is different inside and outside it, i.e., such cylinder is a cluster in itself. In addition, its statistical significance is verified and a relative risk of disease is attributed in relation to the areas not included in the cluster.

The software requires the following data to perform the analyses: geographic location of each analysis unit (in our study, district centroids), number of cases per temporal analysis unit (number of childhood cancer cases in children aged 0-14 years old per district, per year), the population at risk per unit, per year (total number of children aged 0-14 years old per district, per year). To establish the population at risk per year of analysis, population data provided by the National Censuses of Population and Housing of 2001 and $2010^{12,17}$ were used. These data were extrapolated using the AGEINT template, which is part of the Population Analysis Spreadsheets developed by the U.S. Census Bureau. ${ }^{18}$

Analyses were done considering the total tumors group (total tumors) and subgroups included in the database as per the two classifications mentioned above. In addition, age and sex were introduced as covariates to assess whether adding data shaped or influenced clusters.

\section{RESULTS}

The Registry of Tumors of the Province of Córdoba provided data on 1098 cases of children aged 0-14 years old with malignant tumors diagnosed in Córdoba between 2004 and 2013. Cases were classified based on two international nomenclatures.

Table 1 shows the number of cases per year and the annual crude incidence rate of the different cancer groups classified as per the ICCC-3. The indicators from this table were compared to those of the Argentine Hospital Oncopediatric Registry; some differences were observed that may not be statistically verified, and that we believe are rather related to data management than to their origin. ${ }^{19}$

Table 2 shows the frequency of cases per year, the crude rate and the standardized rate of childhood cancer in Córdoba by district (20042013). It is worth noting the low frequency of 
childhood cancer in some districts, which is even null for some or several years (e.g., no cases were observed in the Pocho district over the entire study period). In addition, the size of the child population in some districts is small, which makes estimated rates fluctuate due to data variability among and within geographic units in different years.

Table 3 and Figure 1 describe each spatial cluster and associated parameters observed in the province of Córdoba over the studied period. The introduction of unclassified data led to the detection of a significant spatial cluster $(p=0.01)$ for total tumors in the Capital and Colón districts. The following results were obtained using the data classified as per the two international nomenclatures: a significant spatial cluster for leukemias $(p=0.02)$ in the Capital, Río Primero, Río Segundo, and Tercero Arriba districts; a significant spatial cluster for renal tumors $(p=0.01)$ in the Cruz del Eje, Minas, Pocho, Punilla, San Alberto, San Javier, and Santa María districts; a significant spatial cluster for central nervous system tumors $(p=0.03)$ in the Capital and Colón districts; and a significant spatial cluster for primary or presumably primary malignant neoplasms of lymphoid, hematopoietic and related tissue $(p=0.03)$ in the Capital, Río Primero, Río Segundo, and Tercero Arriba districts (consistent, in terms of geographic distribution, with the leukemia cluster shown in Figure 1).

The spatial-temporal analysis detected a significant cluster for neuroblastoma and other peripheral nervous cell tumors $(p=0.02)$ in the Capital, Colón, and Santa María districts in the 2009-2010 period (Figure 2). The software used a crude rate of 9 cases per one million children aged 0-14 years old as a global parameter. Twenty cases were observed within this cluster, although as per the software estimations, 7.5 cases were expected (a $168 \%$ difference). The crude rate estimated for this cluster was 25 cases per one million children aged 0-14 years old, with a relative risk of 3.29.

Finally, the temporal analysis showed only one significant result $(p=0.01)$ for the neuroblastoma and other peripheral nervous cell tumors group in the 2009-2010 period. The software used a crude rate of 9 cases per one million children aged 0-14 years old as a global parameter; 27 cases were found, although as per the software estimations,

TABLE 1. Number of cases per year and crude incidence rate for the different childhood cancer groups classified as per the International Classification of Childhood Cancer, 3rd edition. Province of Córdoba, Argentina, 2004-2013 period

\begin{tabular}{|c|c|c|c|c|c|c|c|c|c|c|c|c|c|c|}
\hline ICCC group & 2004 & 2005 & 2006 & 2007 & 2008 & 2009 & 2010 & 2011 & 2012 & 2013 & $\begin{array}{c}\text { Cases } \\
2004 / 13\end{array}$ & $\begin{array}{c}\text { Average } \\
\text { cases }\end{array}$ & $\%$ & $\begin{array}{l}\text { Crude } \\
\text { rate }^{*}\end{array}$ \\
\hline I. Leukemias & 30 & 27 & 31 & 32 & 28 & 36 & 37 & 41 & 40 & 32 & 334 & 33.4 & 30.4 & 41.4 \\
\hline $\begin{array}{l}\text { II. Lymphomas and } \\
\text { reticuloendothelial neoplasms }\end{array}$ & 15 & 19 & 20 & 12 & 20 & 4 & 14 & 15 & 17 & 10 & 146 & 14.6 & 13.3 & 18.1 \\
\hline $\begin{array}{l}\text { III. Tumors of the } \\
\text { central nervous system }\end{array}$ & 24 & 24 & 20 & 16 & 21 & 19 & 22 & 17 & 19 & 16 & 198 & 19.8 & 18.0 & 24.5 \\
\hline $\begin{array}{l}\text { IV. Neuroblastoma and other } \\
\text { peripheral nervous cell tumors }\end{array}$ & 3 & 9 & 7 & 7 & 8 & 12 & 15 & 7 & 2 & 5 & 75 & 7.5 & 6.8 & 9.3 \\
\hline V. Retinoblastoma & 3 & 2 & 4 & 6 & 4 & 8 & 3 & 6 & 2 & 1 & 39 & 3.9 & 3.6 & 4.8 \\
\hline VI. Renal tumors & 8 & 5 & 5 & 8 & 4 & 7 & 5 & 4 & 5 & 5 & 56 & 5.6 & 5.1 & 6.9 \\
\hline VII. Hepatic tumors & 2 & 2 & 0 & 2 & 2 & 2 & 4 & 1 & 1 & 3 & 19 & 1.9 & 1.7 & 2.4 \\
\hline VIII. Bone tumors & 6 & 7 & 6 & 3 & 9 & 7 & 8 & 4 & 6 & 6 & 62 & 6.2 & 5.6 & 7.7 \\
\hline IX. Soft tissue tumors & 4 & 3 & 7 & 2 & 2 & 3 & 11 & 6 & 4 & 8 & 50 & 5 & 4.6 & 6.2 \\
\hline X. Germ cell tumors & 7 & 6 & 6 & 12 & 8 & 4 & 6 & 6 & 5 & 5 & 65 & 6.5 & 5.9 & 8.1 \\
\hline $\begin{array}{l}\text { XI. Carcinomas and other } \\
\text { epithelial tumors }\end{array}$ & 6 & 6 & 2 & 1 & 6 & 2 & 4 & 3 & 3 & 1 & 34 & 3.4 & 3.1 & 4.2 \\
\hline XII. Other and unspecified tumors & 1 & 4 & 0 & 3 & 3 & 3 & 3 & 0 & 2 & 1 & 20 & 2 & 1.8 & 2.5 \\
\hline Total & 109 & 114 & 108 & 104 & 115 & 107 & 132 & 110 & 106 & 93 & 1098 & 109.8 & 100.0 & 136.1 \\
\hline
\end{tabular}

ICCC: International Classification of Childhood Cancer.

* Average incidence in children younger than 15 years old per 1000000 children.

Source: prepared by the author based on data provided by the Registry of Tumors of the Province of Córdoba and the National Censuses of Population and Housing of 2001 and 2010.12,13,17 
TABle 2. Frequency of cases per year, crude rate and standardized rate by district. Province of Córdoba, Argentina, 20042013 period

\begin{tabular}{|c|c|c|c|c|c|c|c|c|c|c|c|c|c|c|}
\hline District & $\begin{array}{l}\text { Avg. } \\
\text { pop.* }\end{array}$ & $\begin{array}{c}\text { Cases } \\
2004\end{array}$ & 2005 & 2006 & 2007 & 2008 & 2009 & 2010 & 2011 & 2012 & 2013 & Total & $\begin{array}{l}\text { Crude } \\
\text { rate }^{* *}\end{array}$ & $\begin{array}{c}\text { Est. } \\
\text { rate }^{* * *}\end{array}$ \\
\hline Calamuchita & 13698 & 3 & 0 & 2 & 5 & 1 & 1 & 2 & 1 & 2 & 2 & 19 & 138.7 & 137.0 \\
\hline Capital & 316757 & 44 & 54 & 54 & 41 & 54 & 44 & 61 & 47 & 42 & 40 & 481 & 151.9 & 155.6 \\
\hline Colón & 60998 & 10 & 8 & 7 & 7 & 9 & 9 & 11 & 10 & 13 & 7 & 91 & 149.2 & 151.2 \\
\hline Cruz del Eje & 16236 & 1 & 3 & 1 & 3 & 2 & 1 & 5 & 0 & 1 & 2 & 19 & 117 & 128.9 \\
\hline General Roca & 8990 & 0 & 1 & 0 & 0 & 2 & 2 & 0 & 0 & 1 & 1 & 7 & 77.9 & 84.5 \\
\hline General San Martín & 30396 & 2 & 6 & 4 & 4 & 6 & 5 & 2 & 1 & 4 & 7 & 41 & 134.9 & 135.3 \\
\hline Ischilín & 8918 & 1 & 0 & 2 & 1 & 1 & 1 & 0 & 1 & 2 & 1 & 10 & 112.1 & 113.7 \\
\hline Juárez Celman & 15126 & 3 & 0 & 2 & 2 & 1 & 0 & 0 & 3 & 2 & 0 & 13 & 85.9 & 89.3 \\
\hline Marcos Juárez & 22837 & 3 & 2 & 1 & 2 & 3 & 0 & 1 & 4 & 2 & 2 & 20 & 87.6 & 133.3 \\
\hline Minas & 1323 & 0 & 0 & 2 & 0 & 0 & 0 & 0 & 0 & 0 & 0 & 2 & 151.2 & 208.3 \\
\hline Pocho & 1440 & 0 & 0 & 0 & 0 & 0 & 0 & 0 & 0 & 0 & 0 & 0 & 0 & 0 \\
\hline Pte. Roque Sáenz Peña & 9083 & 1 & 3 & 0 & 2 & 0 & 0 & 2 & 2 & 0 & 1 & 11 & 121.1 & 123.8 \\
\hline Punilla & 41742 & 6 & 6 & 6 & 4 & 7 & 10 & 6 & 8 & 2 & 3 & 58 & 138.9 & 136.6 \\
\hline Río Cuarto & 56804 & 6 & 11 & 4 & 4 & 3 & 9 & 5 & 7 & 4 & 8 & 61 & 107.4 & 110.2 \\
\hline Río Primero & 12937 & 4 & 2 & 1 & 3 & 0 & 1 & 3 & 1 & 2 & 0 & 17 & 131.4 & 138.1 \\
\hline Río Seco & 4077 & 2 & 1 & 0 & 0 & 1 & 0 & 1 & 1 & 0 & 0 & 6 & 147.2 & 150.6 \\
\hline Río Segundo & 25491 & 4 & 3 & 1 & 3 & 5 & 8 & 2 & 5 & 4 & 6 & 41 & 160.8 & 164.9 \\
\hline San Alberto & 10293 & 2 & 2 & 2 & 3 & 2 & 2 & 1 & 0 & 3 & 0 & 17 & 165.2 & 173.7 \\
\hline San Javier & 14217 & 1 & 2 & 3 & 4 & 1 & 1 & 3 & 2 & 2 & 3 & 22 & 154.7 & 167.7 \\
\hline San Justo & 49919 & 6 & 4 & 6 & 6 & 5 & 4 & 8 & 8 & 5 & 1 & 53 & 106.2 & 110.7 \\
\hline Santa María & 25154 & 2 & 1 & 2 & 3 & 2 & 2 & 6 & 4 & 4 & 3 & 29 & 115.3 & 121.3 \\
\hline Sobremonte & 1314 & 0 & 0 & 0 & 0 & 0 & 0 & 1 & 1 & 0 & 0 & 2 & 152.2 & 132.8 \\
\hline Tercero Arriba & 25972 & 2 & 5 & 3 & 2 & 6 & 1 & 5 & 1 & 6 & 3 & 34 & 130.9 & 135.2 \\
\hline Totoral & 5116 & 1 & 0 & 0 & 1 & 0 & 3 & 0 & 1 & 0 & 0 & 6 & 117.3 & 123.9 \\
\hline Tulumba & 3412 & 0 & 0 & 0 & 1 & 1 & 0 & 1 & 0 & 0 & 1 & 4 & 117.2 & 139.9 \\
\hline Unión & 25129 & 5 & 0 & 5 & 3 & 3 & 3 & 6 & 2 & 5 & 2 & 34 & 135.3 & 141.7 \\
\hline Total & 807377 & 109 & 114 & 108 & 104 & 115 & 107 & 132 & 110 & 106 & 93 & 1098 & 136 & 139.4 \\
\hline
\end{tabular}

* Average population of children aged 0-14 years old for the 2004-2013 period (source: National Censuses of 2001 and 2010). ${ }^{12,17}$

** Annual crude rate per one million children aged 0-14 years old.

*** Standardized rate using the direct method of the "old standard world population" defined by Doll and Waterhouse and recommended by the World Health Organization. ${ }^{14}$

Source: prepared by the author based on data provided by the Registry of Tumors of the Province of Córdoba and the National Censuses of Population and Housing of 2001 and 2010.12,13,17

TABLE 3. Significant spatial clusters of childhood cancer incidence observed in the province of Córdoba, Argentina, 2004-2013 period

\begin{tabular}{|c|c|c|c|c|c|c|}
\hline $\begin{array}{l}\text { Group defining } \\
\text { the cluster }\end{array}$ & $\begin{array}{l}\text { Districts included } \\
\text { in the cluster }\end{array}$ & $\begin{array}{c}\text { Observed } \\
\text { cases* }\end{array}$ & $\begin{array}{c}\text { Expected } \\
\text { cases }^{* *}\end{array}$ & $\begin{array}{c}\text { Obs. cases/ } \\
\text { exp. cases }\end{array}$ & $\begin{array}{c}\text { Relative } \\
\text { risk }\end{array}$ & $\begin{array}{c}\text { Crude incidence } \\
\text { rate*** }^{* * *}\end{array}$ \\
\hline Total tumors & Capital and Colón & 572 & 513.7 & 1.11 & 1.24 & 151 \\
\hline Leukemias (ICCC I) & $\begin{array}{c}\text { Capital, Río Primero, } \\
\text { Río Segundo and Tercero Arriba }\end{array}$ & 188 & 157.7 & 1.19 & 1.44 & 49 \\
\hline Renal tumors (ICCC VI) & $\begin{array}{l}\text { Cruz del Eje, Minas, Pocho, Punilla, } \\
\text { San Alberto, San Javier and Santa María }\end{array}$ & 18 & 7.6 & 2.35 & 2.99 & 16 \\
\hline $\begin{array}{l}\text { Tumors of the central nervous } \\
\text { system (ICD-10 C69-C72) }\end{array}$ & Capital and Colón & 137 & 111.4 & 1.23 & 1.54 & 36 \\
\hline ICD-10 C81-C96 group ${ }^{* * * *}$ & $\begin{array}{c}\text { Capital, Río Primero, } \\
\text { Río Segundo and Tercero Arriba }\end{array}$ & 262 & 226.6 & 1.16 & 1.34 & 69 \\
\hline
\end{tabular}

ICCC: International Classification of Childhood Cancer; ICD: International Classification of Diseases.

* Cases observed within the cluster as per the database.

** Cases expected within the cluster as per the SaTScan software estimation.

*** Per 1000000 inhabitants, within the cluster as estimated by the SaTScan software.

**** Primary or presumably primary malignant neoplasms of lymphoid, hematopoietic and related tissue (ICD-10 C81-C96).

Source: prepared by the author based on data provided by the Registry of Tumors of the Province of Córdoba and the National Censuses of Population and Housing of 2001 and 2010.12,13,17 
FIGURE 1. Maps of some significant spatial clusters of childhood cancer incidence in the province of Córdoba, Argentina, 2004-2013 period

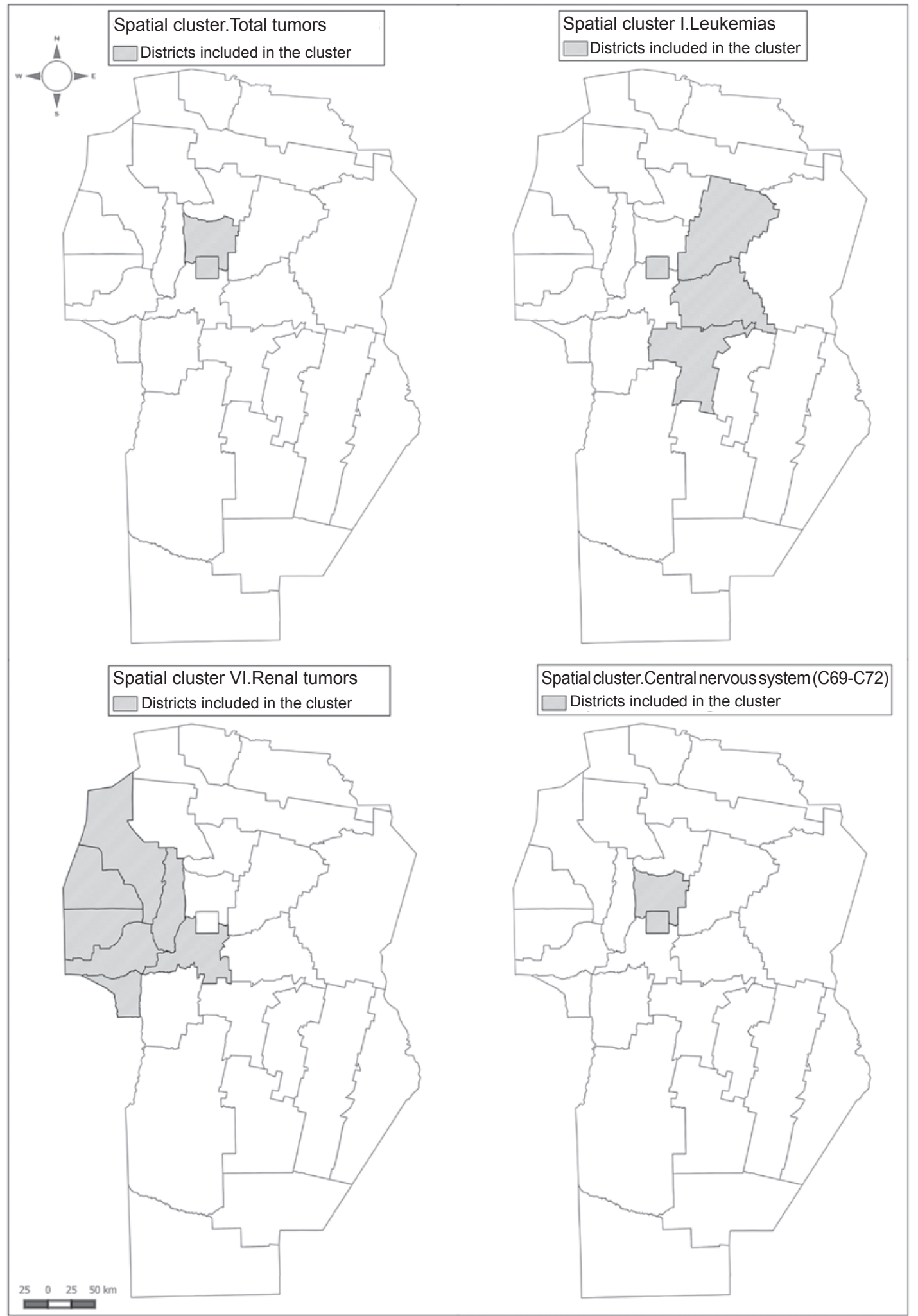

Source: estimated based on data provided by the Registry of Tumors of the Province of Córdoba (2004-2013) and the National Censuses of Population and Housing of 2001 and 2010. ${ }^{12,13,17}$ 
14.9 cases were expected (an $80 \%$ difference), with a relative risk of 2.26 .

The introduction of the age and sex covariates into the software provided the same results as without them. This suggests that such covariates do not shape or influence data aggregation into clusters.

\section{DISCUSSION}

We believe our research provides information on the geographic and temporal distribution of childhood cancer in the province of Córdoba as a first methodological step to advance in the epidemiological study of this type of cancer. This will allow for further, more specific research aimed at studying the risk factors of childhood cancer and its etiology. One of the disadvantages of working with registries of childhood cancer is

FIGURE 2. Significant spatial-temporal cluster for group IV: Neuroblastoma and other peripheral nervous cell tumors, 2009-2010, in the province of Córdoba, Argentina

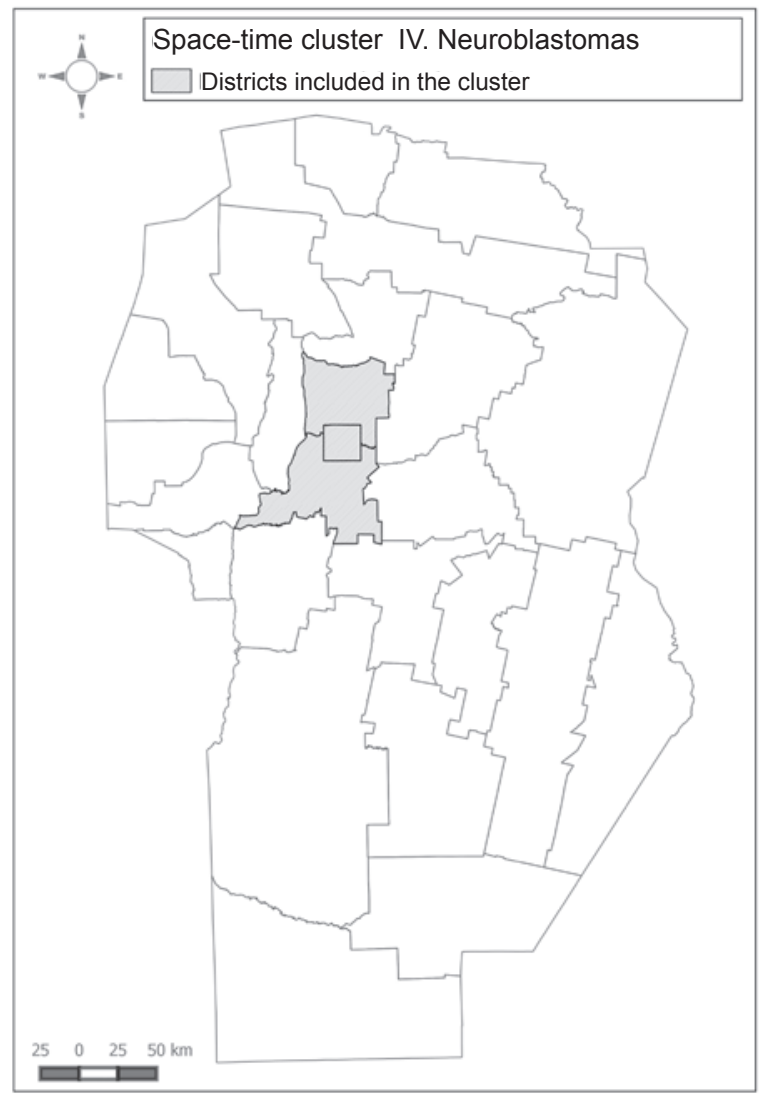

Source: estimated based on data provided by the Registry of Tumors of the Province of Córdoba (2004-2013) and the National Censuses of Population and Housing of 2001 and 2010. 12,13,17 its low incidence, which results in methodological challenges in terms of data consistency. ${ }^{7}$ Although we were able to work with data corresponding to a ten-year period provided by the Registry of Tumors of the Province of Córdoba, it is important to continue corroborating results in the following years considering that the registry is rather recent and is under constant review. ${ }^{13}$ In the future, the plan involves working with data from children and youth aged 0-19 years old to widen case reporting and include an age group whose characteristics is more related to child and adolescent development than to the adult stage.

The cluster-associated indicators observed in our research stress the importance of further deepening analyses in such geographic areas. In addition, it is worth noting the following characteristics of some of the clusters observed in our study: the spatial cluster for total tumors is especially important because it covers $52 \%$ of the database (572 out of 1098 cases), and is concentrated in two out of the 26 provincial districts (Capital and Colón), the place of residence of $47 \%$ of the child population. ${ }^{12}$ The spatial cluster for leukemias (ICCC I) and for primary or presumably primary malignant neoplasms of lymphoid, hematopoietic and related tissue (ICD-10, C81-C96) also stands out because of the large child population in the region included in the cluster and, at the same time, because it encompasses the largest childhood cancer group (leukemias). The spatial cluster for renal tumors (ICCC VI) is particularly striking because it includes a type of cancer that is uncommon in children but evidences very high associated indicators (observed/expected ratio, relative risk, and rate within the cluster). In addition, it is located in a very definite and distinct geographic area compared to the rest of the clusters that show geographic overlapping. Finally, the analysis of results from the spatial-temporal cluster for neuroblastoma and other peripheral nervous cell tumors (ICCC IV) emphasizes the specificity of the analysis to detect the cluster in two particular years across the period, with high associated indicators. The result of the temporal cluster for the same group indicates that the incidence peaked across the province in the 2009-2010 period. This finding is probably the result of including the incidence of the three districts (Capital, Colón, and Santa María) in the total for the province for this period.

Although there are other studies conducted in Córdoba that analyze geographic distribution patterns, ${ }^{20-23}$ they do not always include data 
on incidence. In addition, those investigations were done in a global age group or in adults only. A separate analysis is critical in the case of childhood cancer because its dynamics is absolutely different from that of adults. ${ }^{3,7}$

The lack of studies on childhood cancer conducted in Argentina using the same methodology or tools as in this study may be considered a disadvantage because it is not possible to compare results that would certainly improve the approach to this problem. In turn, it is critical to create interdisciplinary research and working groups to establish monitoring, research and prevention systems targeted at childhood cancer and its risk factors in Argentina.

At an international level, there are several studies that applied different methodologies to analyze the spatial-temporal distribution of childhood cancer to establish clusters. Although they cannot be directly compared, those studies found, as in our study, clusters within the large groups of total tumors, leukemias, tumors of the central nervous system, and lymphomas., ${ }^{74-31}$ However, those studies failed to establish a conclusive relationship between results and a socioenvironmental factor, even though the presence of clusters is probably an evidence of the fact that environmental factors are related to the presence and development of cancer. ${ }^{32-34}$ Apart from ionizing radiation and some congenital genetic syndromes, there is little evidence - and lots of suspicion - regarding other factors that may influence the clustering of childhood cancer. For example, unidentified infectious agents, ${ }^{29,30}$ agrochemicals and pesticides, ${ }^{29,30}$ pollutants in the air or the water, ${ }^{34,35}$ polluting industrial products or waste (due to parental occupational exposure or direct environmental exposure). ${ }^{29,32,34}$

It is worth noting that most of those studies, as our study, highlight the power of the methodologies that assess spatial-temporal patterns as statistical tools that make it possible to focus on areas or populations where the rates of childhood cancer are unusually high and, as a result, to study its risk factors and etiology. $7,25,28,31$

There are several disease spatial-temporal analysis software programs, but SaTScan stands out because it is designed for rare statistical events (and uses case individual count in its analyses). This feature makes it optimal for the study of childhood cancer, which is a very rare disease. Among cluster-associated indicators, the relative risk estimated by SaTScan is specific to this software, so it makes it possible to know the risk for an event (presence of disease) within the cluster compared to the rest of the studied region. It also enables the introduction of covariates, which makes it possible to test factors that may influence their distribution. Finally, an approach using other statistical software methodologies would be more difficult because they use data summarized into similar indicators or rates that assume a loss of resources due to the small size of populations. ${ }^{7}$

There are few studies conducted in Argentina that analyze the spatial-temporal distribution of cancer, let alone in children. Results obtained in our study open the way for new, future research hypotheses, with the advantage of limiting to particular geographic areas and thus start understanding more of the epidemiological dynamics of childhood cancer. In addition, this study has demonstrated the usefulness of a tool that may be extrapolated to other age groups and used in different geographic scales to monitor population health.

\section{CONCLUSIONS}

Significant clusters were determined, with important associated indicators observed in several districts of Córdoba. This is the first methodological step towards the development of new investigations on the risk factors for childhood cancer and its etiology.

\section{Acknowledgments}

I would like to thank the managerial and administrative staff of the Tumor Registry of the Province of Córdoba for providing the data for this investigation. $\mathrm{n}$

\section{REFERENCES}

1. Barragán SL. Perfil Epidemiológico en Argentina. In Barragán HL, ed. Fundamentos de Salud Pública. La Plata: Universidad Nacional de La Plata; 2007.Págs.191-229.

2. Pujol CJ, Bertone CL, Acosta LD. Morbimortalidad por cáncer infantil en la República Argentina. 2006-2008. Arch Argent Pediatr 2014;112(1):50-4.

3. Fajardo-Gutiérrez A,Mejía AranguréJM,Hernández-Cruz L,Mendoza-SánchezHF, etal. Epidemiología descriptiva de las neoplasias malignas en niños. Rev Panam Salud Pública 1999;6(2):75-88.

4. Ferrís Tortajada J, Ortega-García JA, Aliaga-Vera J, OrtíMartín A, et al. Introducción: el niño y el medio ambiente. An Esp Pediatr 2002;56(Supl 6):353-9.

5. Ferrís Tortajada F, Ortega-García JA, Marco Macián A, García Castell J. Medio ambiente y cáncer pediátrico. An Pediatr (Barc) 2004;61(1):42-50.

6. Ries LA, Smith MA, Gurney JG, Linet M, et al. Cancer incidence and survival among children and adolescents: United States SEER Program 1975-1995. Bethesda: National Cancer Institute; 1999. 
7. Ortega-García JA, López-HernándezFA,Cárceles-Álvarez A, Santiago-Rodríguez EJ, et al. Análisis en áreas pequeñas del cáncer pediátrico en el municipio de Murcia. An Pediatr (Barc) 2016;84(3):154-62.

8. Firth M, Brophy J, Kate M. Workplace Roulette: Gambling With Cancer. Ontario: Between The Lines; 1996:7-15.

9. Carroquino MJ, Galson SK, Licht J, Amler RW, et al. The U.S. EPA Conference on Preventable Causes of Cancer in Children: a research agenda. Environ Health Perspect 1998;106(Suppl 3):867-73.

10. Reuben SH. Reducing Environmental Cancer Risk: What We Can Do Now. Bethesda: National Cancer Institute; 2010:1-24.

11. Barcellos C. Unidades y escalas en los análisis espaciales en salud. Rev Cubana Salud Publica 2003;29(4):307-13.

12. Instituto Nacional deEstadística y Censo. Censo Nacional de Población, Hogares y Viviendas 2010. Buenos Aires:INDEC; 2011. [Accessed on: April 15 $\left.{ }^{\text {th }}, 2014\right]$. Available at: http:// www.indec.gov.ar/nivel4_default.asp?id_tema_1=2\&id_ tema_2=41\&id_tema_3=135.

13. Ley N. ${ }^{\circ} 9769$. Régimen del Registro Provincial de Tumores de la Provincia de Córdoba. Boletín oficial del Gobierno de la provincia de Córdoba. Córdoba, Argentina, 7 de abril de 2010.

14. Doll R, Payne P, Waterhouse J, eds. Cancer Incidence in Five Continents, Vol. 1. Geneva: Union Internationale Contre le Cancer; 1966.

15. Subdirección de Cartografía y S.I.G. Geo Portal [Internet]. Córdoba: Gobierno de la Provincia de Córdoba; 2014. [Accessed on: March 1 $\left.{ }^{\text {st }}, 2015\right]$. Available at: http:// estadistica.cba.gov.ar/Territorio/GeoPortal/tabid/564/ language/es-AR/Default.aspx.

16. Kulldorff M. SaTScan T.M. User Guide for version 9.4. Boston: SaTScan; 2015. [Accessed on: June 24 $4^{\text {th }}, 2016$ ]. Available at: http://www.satscan.org/cgi-bin/satscan/ register.pl/Sa TScan_Users_Guide.pdf?todo=process_ userguide_download.

17. Instituto Nacional de Estadística y Censo. Censo Nacional de Población, Hogares y Viviendas 2001. Buenos Aires: INDEC; 2002. [Accessed on: June 24 ${ }^{\text {th }}, 2016$ ]. Available at: http://www.indec.gov.ar/micro_sitios/webcenso/index. asp.

18. United States Census Bureau. Population Analysis System (PAS) Overview. Suitland: US Census Bureau; 1994. [Accessed on: May 20 $\left.{ }^{\text {th }}, 2014\right]$. Available at: https://www. census.gov/population/international/software/pas/.

19. MorenoF. Registro Oncopediátrico Hospitalario Argentino (ROHA). Resultados 2000-2008. 3.ra ed. Buenos Aires: Fundación Kaleidos; 2010.Págs.40-41.

20. Díaz MP, Osella AR, Aballay LR, Muñoz SE, et al. Cancer incidence pattern in Córdoba, Argentina. Eur J Cancer Prev 2009;18(4):259-66.

21. DíazMP,CorrenteJE, Osella AR, MuñozSE, et al. Modeling spatial distribution of cancer incidence in Córdoba, Argentina. Apple Cancer Res 2010;30(2):245-52.
22. Pou SA, Tumas N, Sánchez-Soria D, Díaz MP. Mortalidad por cáncer en Córdoba, Argentina: distribución espacial y análisis de tendencias durante el periodo 1986-2011 [Internet]. [Accessed on: November $10^{\text {th }}, 2014$ ]. Available at: http:/ /www.alapop.org/Congreso2014/DOCSFINAIS_ PDF/ALAP_2014_FINAL98.pdf.

23. Agost L, Pujol C, Bertone C. Análisis de la incidencia del cáncer por departamento en la provincia de CórdobaArgentina (2004-2008): tasas de incidencia y detección de conglomerados espaciales. Cuestiones de Población y Sociedad 2015;5(5):9-23.

24. Zhan BF. Childhood cancer clusters in New Mexico, 19731997. Southwestern Geographer 2001;(5):31-48.

25. Wheeler DC. A comparison of spatial clustering and cluster detection techniques for childhood leukemia incidence in Ohio, 1996-2003. Int J Health Geogr 2007;6:13.

26. McNally RJ, Bithell JF, Vincent TJ, Murphy MF. Spacetime clustering of childhood cancer around the residence at birth. Int J Cancer 2009;124(2):449-55.

27. Mosavi-Jarrahi A, Moini M, Mohagheghi MA, Alebouyeh $\mathrm{M}$, et al. Clustering of childhood cancer in the inner city of Tehran metropolitan area: a GIS-based analysis. Int $J$ Hyg Environ Health 2007;210(2):113-9.

28. Torabi M, Rosychuk RJ. An examination of five spatial disease clustering methodologies for the identification of childhood cancer clusters in Alberta, Canada. Spat Spatiotemporal Epidemiol 2011;2(4):321-30.

29. Wheeler DC, De Roos AJ, Cerhan JR, Morton LM, et al. Spatial-temporal analysis of non-Hodgkin lymphoma in the NCI-SEER NHL case-control study. Environ Health 2011;10:63.

30. McNally RJ, Stiller C, Vincent TJ, Murphy MF. Crossspace-time clustering of childhood cancer in Great Britain: evidence for a common aetiology. Int J Cancer 2014;134(1):136-43.

31. Amin R, Hendryx M, Shull M, Bohnert A. A cluster analysis of pediatric cancer incidence rates in Florida: 2000-2010. Stat Public Policy (Phila) 2014;1(1):69-77.

32. McGlinn LA. Cancer Clusters in the United States since 1995: considering the value of their investigation. Middle States Geographer 2006;39:69-75.

33. Eden T. Aetiology of childhood leukaemia. Cancer Treat Rev 2010;36(4):286-97.

34. Duarte-Rodríguez DA, McNally RJ, Núñez-Enríquez JC, Fajardo-Gutiérrez A, et al. Etiological Research of Childhood Acute Leukemia with Cluster and Clustering Analysis. In: Mejía-Arangure JM, ed. Clinical Epidemiology of Acute Lymphoblastic Leukemia - From the Molecules to the Clinic. México: InTech; 2013:115-44.

35. Fagliano JA, Berry M, Kohler BA, Klotz JB, et al. CaseControl Study of Childhood Cancers in Dover Township (Ocean County), New Jersey. New Jersey: New Jersey Department of Health and Senior Services; 2003:1-26. 